\title{
Performance of university technology transfer offices: evidence from Europe and Japan
}

\author{
Szabolcs Pronay \\ University of Szeged, Szeged, Hungary \\ Tamara Keszey \\ Corvinus University of Budapest, Budapest, Hungary \\ Norbert Buzás \\ University of Szeged, Szeged, Hungary \\ Takayuki Sakai \\ Faculty of Science, Graduate School of Science, Kobe University, Kobe, Japan, and \\ Kensuke Inai \\ University of Tokushima, Tokushima, Japan
}

\begin{abstract}
Purpose - This study aims to improve the understanding of the factors that influence the performance of universities' technology transfer offices (TTOs), units charged with the responsibility for aiding the commercialization of research innovations.

Design/methodology/approach - To empirically test the link between factors affecting TTO performance and whether these effects are contingent on a country-specific environment, survey data were collected from 187 TTO stakeholders (TTO heads, TTO employees and university researchers) in 18 countries of Europe and Japan, and structural equation modeling (SEM) was used.

Findings - The results show that the internal embeddedness of a TTO within a university is the most important factor in determining a TTO's performance. A TTO's performance is positively affected by its marketing capabilities and social embeddedness. Strict patent portfolio management has no significant impact on TTO performance in Japan and has a negative effect on European TTOs' performance.

Originality/value - This study highlights the role of organizational and interorganizational factors in TTO performance; moreover, this is one of the few multi-continent (Europe and Asia) studies in the domain of university-industry collaborations, expanding the current understanding of the contingent roles of the region of operation, which has remained unexplored, as extant studies were typically conducted in only one country.
\end{abstract}

Keywords University-business collaboration, Technology transfer office, Structural equation modeling,

Knowledge-based view

Paper type Research paper

\section{Introduction}

Over the last decades, universities' traditional mission of teaching and research has changed and been amended with the so-called "third mission," referring to activities that connect universities with the rest of society through knowledge transfers between universities and industry, business, government and society (Laredo, 2007). The third mission refers to all activities concerned with the generation, use, application and exploitation of knowledge and other university capabilities outside academic environments for the purpose of representing an essential source of innovation for these external actors and serving as an engine of societal and economic development for regions and countries (Molas-Gallart and Castro-Martínez, 2007). Universities need to step out of the academic sphere and establish value-creating relations not only with businesses but also with the public sector (external stakeholders) and thus go beyond the traditional first and second missions of education and research (Bozeman et al., 2015).

Received 5 March 2020 Revised 23 September 2020 Accepted 22 November 2020
University technology transfer offices 
University actors, however, are traditionally comfortable within habitual academic frameworks; additionally, collaboration with external stakeholders requires specific new skills that researchers and universities often lack (Sandström et al., 2016; Angiola et al., 2018). Recognizing the need to assist academics with engagement in specific domains of activities with external stakeholders and aid collaborations, many-including almost all Europeanuniversities have established so-called technology transfer offices (hereinafter TTOs) (De Beer et al., 2017). TTOs are dedicated for identifying and supporting research within universities that are of potential commercial interest and formulating strategies for how to exploit it. The primary motives of TTOs are to protect and commercialize the university's intellectual property (IP), while the secondary motives are to facilitate technological diffusion and secure additional research funding (Siegel et al., 2003).

However, measuring the performance of university TTOs, which is typically based on capturing tangible metrics of the conversion ratio from "inputs" to "outputs" of technology transfer, raises issues that are highly relevant from a managerial perspective (De Beer et al., 2017). The third mission also involves universities making efforts to improve social wellbeing. Yet, the use of purely tangible indicators can give a distorted picture of the real TTO performance of universities and may even reduce performance in the third mission. For instance, Molas-Gallart and Castro-Martínez (2007) claim that available factual data on commercialization (as an example of a tangible indicator) apply to disciplines such as biotechnology, where markets exist close to university research, but not to fields such as the theoretical physics or philosophy, where direct market-based applications are more limited and contributions to civil society and private sector are likely to occur through other channels. The use of purely tangible indicators may not capture the full set of true TTO outputs, potentially leading to flawed strategic decision-making by TTO and university executives (De Beer et al., 2017).

Although there is a great potential for transnational sharing of best practices across TTOs, it is currently limited, considering the contextual factors of countries (De Beer et al., 2017). A high number of extant studies in this domain reveal that different countries and regions differ in terms of the longevity of collaboration between science-based institutions and industry, the performance of academic-industry knowledge transfer in terms of revenue from patents, the size of venture capital fundraising and the strength of institutional ties or financial links with the state, to mention a few (Zaichenko, 2018; Croce et al., 2014; Gerbin and Drnovsek, 2016; Comacchio et al., 2012). While more multi-country research is needed to break down these barriers, empirical studies typically focus on single countries, and only a minimal number of studies are carried out in multiple country and continent environments.

Against these backdrops, building upon emerging results in the literature of universityindustry technology transfer (hereinafter UITT) and recent studies that attribute more "soft skills" to TTO performance (Secundo et al., 2016; De Beer et al., 2017), this study proposes perception-based, intangible TTO performance metrics and measures important variables that influence this performance. To address the aforementioned gap related to the lack of understanding of the pattern differences of technology transfer that may emerge in various countries, this study uncovers whether the role of patent portfolio management contributes to TTO performance differently in Europe than in Japan. To the best of our knowledge, this is one of the first multi-continent studies in the domain of UITT that focuses on TTO performance by comparing European and Japanese TTOs. While European TTOs are rather diverse in terms of state influence, patenting practices, revenues and researchers' positions and attitudes, to mention a few characteristics, Japan has taken a unique path by being a laggard in UITT compared with Europe but has a strong emphasis on patent licensing (Etzkowitz et al., 2008; Ito et al., 2016); hence, Europe and Japan are especially well suited for a study aiming to highlight the roles of contingencies in the region of operation. 
The remainder of this paper is organized as follows. The following section presents the theoretical background of the study and identifies the gaps in the extant body of empirical papers that this paper aims to fill. Then, the conceptual framework and the hypotheses are presented. Next, the study's research method and key findings are shown. The article concludes with a discussion of the study's theoretical contributions, managerial implications, limitations and suggestions for future research.

\section{Theoretical background and research gaps}

This study is theoretically anchored in the UITT literature. Prior studies in this domain have made significant contributions for understanding the various forms of knowledge and technology exchange between universities and nonacademic spheres. These empirically investigated forms include market and nonmarket spillovers (Mowery and Ziedonis, 2015), university-industry research partnerships and alliances (de Wit-de Vries et al., 2018; GalánMuros and Davey, 2017; Estrada et al., 2016), academic spin-offs (Marzocchi et al., 2017; Miranda et al., 2017), new venture projects (M'Chirgui et al., 2016) and academic entrepreneurship (Sandström et al., 2016; Marion et al., 2012; Hayter, 2016; Tartari and Salter, 2015; Forti et al., 2013).

A part of the UITT literature is made up of studies examining the specific role of TTOs in this literature. In this subsection of the UITT literature, three research gaps emerge. First, more research is needed to capture TTO performance beyond tangible metrics. As shown in Table 1, the conceptualization and operationalization of TTO performance is divergent in the extant literature. The effectiveness of university technology transfer is frequently associated with tangible measures, such as the number of patents (e.g. the number of patent applications, the number of patents sold, share of researchers within the university holding more than a specific number of patents, etc.) or the number of indexed publications (e.g. O'Kane et al., 2015; Zaichenko, 2018).

Authors, however, point out those tangible measures may be misleading, as they say little about the quality of the patents or fail to comprehensively capture the technology transfer performance of universities, for example, aiming to contribute to societal well-being (Guerzoni et al., 2014). An early but well-known study notes that "patents are flawed measures (of innovative output), particularly since not all new innovations are patented and since patents differ greatly in their economic impact" (Pakes and Griliches, 1980). MolasGallart and Castro-Martínez (2007) claim "that any approach to data collection and analysis that focuses purely on university commercial activities is likely to miss large and important parts of the picture" and increased attention on IP commercialization strategies may even hamper universities' societal value delivery.

To address these concerns, recent studies have started to place more emphasis on intangible metrics to capture TTO performance. For example, Secundo et al. (2016) proposes a conceptual model that captures key TTO efficiency areas, including IP strategy and policy, organization design and structure, human resources, technology, industry links and networking over various stages of the TTO maturity level, and (De Beer et al., 2017) empirically tests this model in the United Kingdom and various European countries. Other intangible metrics of TTO performance include academics' willingness to cooperate with TTOs or firms' engagement with TTOs (Comacchio et al., 2012; Muscio, 2010).

Second, there is a need for additional research into factors that may affect TTO performance. As Table 1 shows, there are only a limited number of studies that uncover the factors affecting TTO performance. These factors include individual-level antecedents, such as researchers' experience with the patenting system, academic confidence in TTOs and TTO managers' industry background or access to human capital (Muscio, 2010; Comacchio et al., 2012). Studies also reveal that TTO performance is influenced by
University technology transfer offices 


\begin{tabular}{lllll}
\hline Studies & $\begin{array}{l}\text { TTO performance } \\
\text { conceptualization }\end{array}$ & $\begin{array}{l}\text { TTO performance } \\
\text { operationalization }\end{array}$ & $\begin{array}{l}\text { Factors affecting TTO } \\
\text { performance }\end{array}$ & $\begin{array}{l}\text { Country of } \\
\text { investigation }\end{array}$ \\
\hline
\end{tabular}

Empirical papers with tangible metrics

\section{Sellenthin Academics' Patenting of}

(2009) willingness to apply

for patents through the TTO

$\begin{array}{ll}\begin{array}{l}\text { Clarysse } \\ \text { et al. (2011) }\end{array} & \text { TTO efficiency } \\ \begin{array}{l}\text { Zaichenko } \\ \text { (2018) }\end{array} & \begin{array}{l}\text { Technology transfer } \\ \text { performance (not } \\ \text { specifically TTO } \\ \text { performance) }\end{array} \\ \begin{array}{l}\text { Munshaw } \\ \text { et al. (2018) }\end{array} & \begin{array}{l}\text { Outcomes of } \\ \text { university support }\end{array}\end{array}$

Empirical papers with intangible metrics

$\begin{array}{ll}\text { Muscio } & \text { Efficiency and } \\ (2010) & \text { effectiveness }\end{array}$

effectiveness

Comacchio The boundary

et al. (2012) spanning role of

TTOs evaluated by

firms collaborating

with universities

De Beer Efficiency
et al. (2017)

Conceptual papers

$\begin{array}{ll}\text { Sorensen } & \text { Knowledge access } \\ \text { and } & \text { through TTOs }\end{array}$

Chambers

(2008)

Johnson

(2011)

Table 1.

Overview of studies on TTO performance next level and eventual commercialization university research

(Researchers who applied for patents, researchers who hold granted patents and share of researchers with five or more patents)

Number of patent applications of that university

Number of indexed publications

Number of patent applications at the individual level
Sweden and Germany

(2) The reward system of universities' rewards patents

(3) Supporting infrastructure for patenting and commercialization

Not investigated

United

Kingdom

Not investigated

Russia

Not investigated

United States

(1) Academics confidence in TTOs

(2) TTO managers' industry background

(3) Academic research performance

Dichotomous variable (yes/no) whether respondent firms have engaged with TTOs

Self-evaluated indicators of TTO human resource management, networking, university-industry links and networking

(1) Internal qualified human capital

(2) External human capital

(3) R\&D partners research activity

Not investigated (the focus is on how TTO efficiency evolves into the TTO maturity level)

Conceptual paper (no empirical analysis)

Not investigated

Not applicable (conceptual paper)

Conceptual paper; TTO performance is not conceptualized
United

Kingdom and various /not specified/ European countries
Not applicable (conceptual paper)
Not investigated

(continued) 


\begin{tabular}{lllll}
\hline Studies & $\begin{array}{l}\text { TTO performance } \\
\text { conceptualization }\end{array}$ & $\begin{array}{l}\text { TTO performance } \\
\text { operationalization }\end{array}$ & $\begin{array}{l}\text { Factors affecting TTO } \\
\text { performance }\end{array}$ & $\begin{array}{l}\text { Country of } \\
\text { investigation }\end{array}$ \\
\hline $\begin{array}{l}\text { Secundo } \\
\text { et al. }(2016)\end{array}$ & Efficiency & $\begin{array}{l}\text { Self-evaluated } \\
\text { indicators of TTO IP } \\
\text { strategy and policy, } \\
\text { organization design } \\
\text { and structure, human } \\
\text { resource, technology, } \\
\text { industry links and } \\
\text { networking }\end{array}$ & $\begin{array}{l}\text { Not investigated (the } \\
\text { focus is on maturity level } \\
\text { efficiency areas) }\end{array}$ & $\begin{array}{l}\text { Not applicable } \\
\text { (conceptual } \\
\text { paper) }\end{array}$ \\
& & & & \\
& & &
\end{tabular}

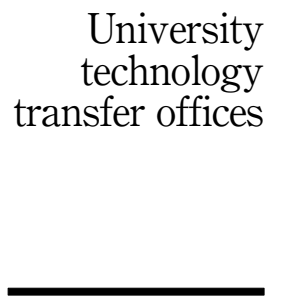

Table 1.

supporting processes, such as the infrastructure of the reward system of the university and supporting infrastructure (Sellenthin, 2009). However, extant empirical studies largely remain silent on how the capabilities of TTOs influence their performance.

Third, studies on both TTOs (see Table 1) and more broadly on university-industry knowledge and technology transfer typically gather single country data; there are a few exceptions with multi-country and multi-continent studies (see Table 2). However, crucial to many academics and practitioners interested in university-industry knowledge and technology transfer is elucidating the understanding of TTO differences in various geographical areas (c.f. De Beer et al., 2017). Scant research highlights that technology transfer systems in Europe differ significantly from those in the United States, with a long history of direct collaboration between science-based institutions and industry (Comacchio et al., 2012). Bacchiocchi and Montobbio (2009) point out that in the United States, university patents are cited more often than companies' patents; however, in Europe and Japan, there is no evidence of a superior abundance of university patents.

\begin{tabular}{|c|c|c|c|}
\hline Study-type & Europe & America and Australia & Asia \\
\hline \multirow[t]{3}{*}{$\begin{array}{l}\text { Single- } \\
\text { country } \\
\text { study }\end{array}$} & Italy (Forti et al., 2013) & $\begin{array}{l}\text { United States (Conti and Liu, 2015; } \\
\text { Jha and Welch, 2010; Marzocchi } \\
\text { et al., 2017; Mowery and Ziedonis, } \\
\text { 2015; Hayter, 2016) }\end{array}$ & $\begin{array}{l}\text { Taiwan (Chen et al., } \\
\text { 2013) }\end{array}$ \\
\hline & $\begin{array}{l}\text { United Kingdom (Tartari and } \\
\text { Salter, 2015; Marzocchi et al., } \\
\text { 2017; Clarysse et al., 2011; Tartari } \\
\text { et al., 2014) }\end{array}$ & Brazil (Freitas et al., 2013) & $\begin{array}{l}\text { South Korea (Park } \\
\text { and Leydesdorff, } \\
\text { 2010) }\end{array}$ \\
\hline & $\begin{array}{l}\text { Spain (Estrada et al., 2016; Criaco } \\
\text { et al., 2014; Olaya Escobar et al., } \\
\text { 2017) } \\
\text { France (Levy et al., 2009) } \\
\text { Russia (Zaichenko, 2018) }\end{array}$ & Australia (Rampersad, 2015) & $\begin{array}{l}\text { Japan (Kodama, } \\
\text { 2008) }\end{array}$ \\
\hline \multirow{5}{*}{$\begin{array}{l}\text { Multi- } \\
\text { country } \\
\text { study } \\
\text { Multi- } \\
\text { continent } \\
\text { study }\end{array}$} & \multicolumn{3}{|c|}{33 countries in Europe (Galán-Muros and Plewa, 2016) } \\
\hline & \multicolumn{3}{|c|}{ Two countries: France and Germany (Robin and Schubert, 2013) } \\
\hline & \multicolumn{3}{|c|}{ Two countries: Sweden and Germany (Sellenthin, 2009) } \\
\hline & \multicolumn{3}{|c|}{$\begin{array}{l}\text { Six countries: Europe (four largest countries), Japan and United States (Bacchiocchi and } \\
\text { Montobbio, 2009) }\end{array}$} \\
\hline & \multicolumn{3}{|c|}{ Four countries: Sweden, Japan, Brazil and United States (Etzkowitz et al., 2008) } \\
\hline
\end{tabular}

Table 2. Geographical dispersion of key empirical studies in the domain of universityindustry collaboration 


\section{Conceptual framework and hypotheses}

Against the gaps introduced in the previous section, we focus on factors affecting TTO performance in countries of Europe and Japan. This study conceptualizes TTO performance as the degree to which TTOs are perceived as being able to effectively commercialize technologies. This conceptualization is in line with recent studies (Zaichenko, 2018; Johnson, 2011) and with the seminal work of Bozeman (2000).

Regarding the variables influencing TTO performance, we build upon knowledge-based view theory. The knowledge-based view has been widely used to examine knowledge management processes in organizations (Nonaka, 1994; Grant, 1996) and is considered a promising theoretical perspective for understanding university entrepreneurship (Hayter, 2016). The knowledge-based view focuses on the kinds of resources and capabilities that organizations should possess to use, apply and exploit the specialist knowledge of their members (Nonaka, 1994; Grant, 1996). According to knowledge-based view theorists, organizations exist to generate and integrate knowledge for subsequent use in strategic actions for sustainable competitive advantage; hence, an organization's ability to acquire new knowledge by generating, renewing and accumulating its knowledge stock becomes critical (Grant, 1996; Spender, 1996). This is especially important for organizations in highly dynamic industries, such as universities where new knowledge is continuously emerging, and organizations that have to maintain a continuous source of new knowledge to gain and sustain competitive advantage.

Knowledge-based view theorists suggest that the process of knowledge management is influenced by organizational support that facilitates the implementation of knowledge management processes (Nonaka, 1994; Grant, 1996). Triggered by the third mission paradigm shift, to facilitate knowledge management processes related to exploitation and transfer of academic knowledge outside the academic environment, universities have to adapt both structurally and strategically. As part of this adaptation process, we consider four antecedent variables and examine how social embeddedness, internal embeddedness, marketing capabilities and patent portfolio management affect TTO performance (see Figure 1).

\subsection{Social embeddedness}

The social sphere gains increasing recognition in the knowledge transfer context. The Quadruple Helix concept (Carayannis and Campbell, 2009) and the responsible innovation approach (Stilgoe et al., 2013) are prime examples of the proliferation of this phenomenon. A related concept, social embeddedness, refers to TTOs' active collaboration in value creation with external stakeholders (civil society and local communities). It is manifested, for example, by taking into consideration local communities during the technology transfer processes, initiating and taking part in open innovation with stakeholders or offering society control over university innovation processes.

Schwartz (2004) claims that "No matter how clever the idea or great the implementation is, an invention typically lives or dies depending on how well it can be integrated into a large social and technological context." When TTOs are socially embedded and have better access and insights into a large "social context," they can develop a larger network of stakeholders that can be called upon during the commercialization of new technologies. Social embeddedness facilitates communication among different actors who are actively involved in the process of technology transfer, leading to higher performance outcomes.

H1. Social embeddedness is positively related to TTO performance.

\subsection{Internal embeddedness}

Internal embeddedness is defined as TTOs' active collaboration in value creation with internal stakeholders, such as researchers. Universities are traditional institutions for basic 

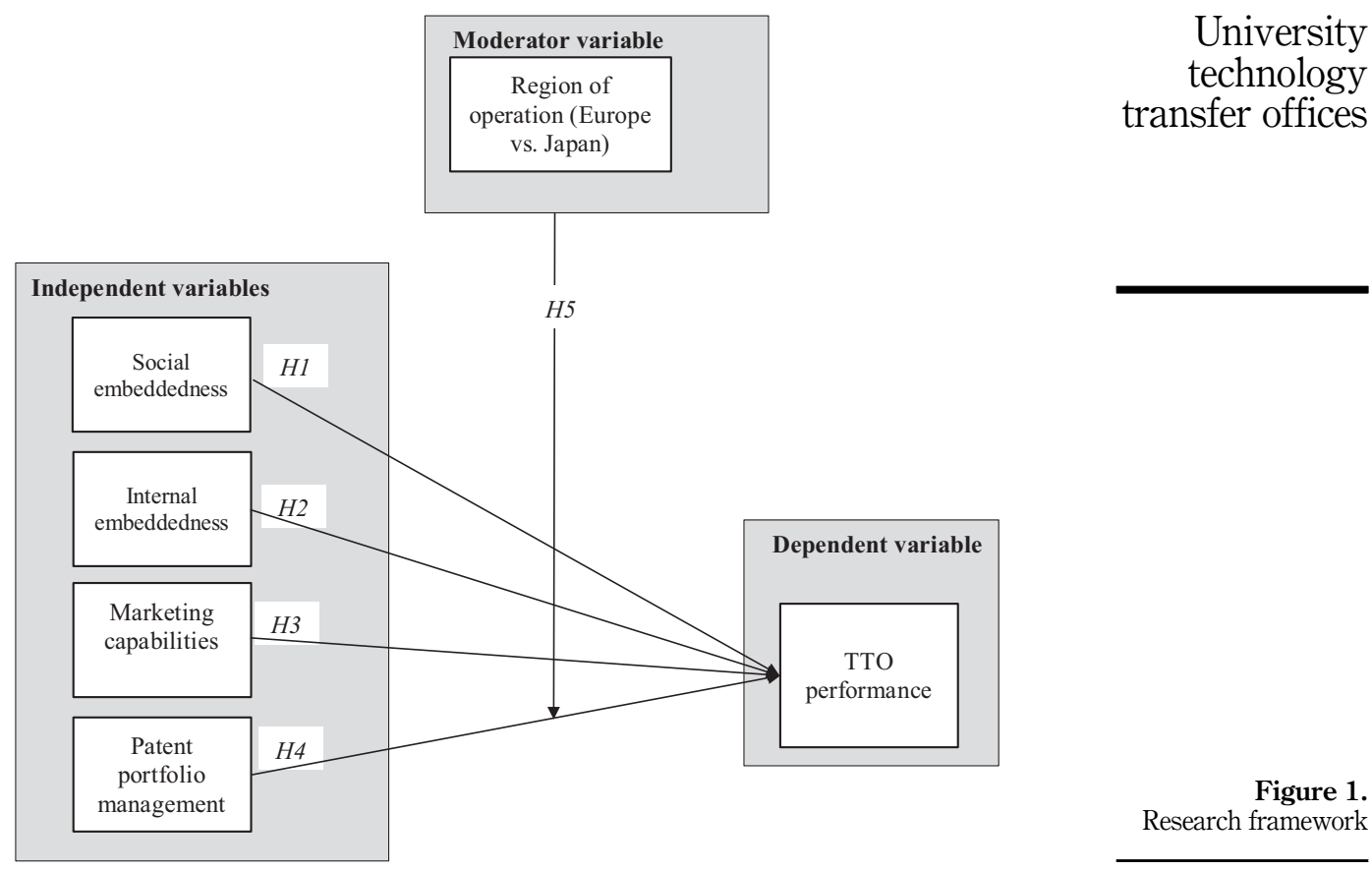

Figure 1. Research framework

research and are considered to be temples of science (Nelson, 2004). As a consequence, a commitment to science is fundamental for researchers working there, a fact that often conflicts with their motivation to commercialize (Haeussler and Colyvas, 2011). Therefore, TTOs need to prove their scientific commitment to become legitimate in the eyes of researchers; however, they often fail to do so, and academics generally do not accept their legitimacy (O’Kane et al., 2015).

Nevertheless, an essential condition of the operation of the TTO is that it maintains appropriate relations with researchers and builds legitimacy in their eyes. Powers (2003) shows that TTOs with a more mature research team hold more patents and sell more licenses. In spite of absent researcher acceptance, researchers may choose the novelty destruction (publication) of IP. Aldridge and Audretsch (2011) highlight the social capital of academics as a central determinant of their likelihood of being involved in knowledge commercialization. However, academics often lack this social capital, which hampers commercialization. When TTOs have good social links and are well embedded internally, they can assist academics in patching structural holes in their networks. Consequently, the TTO needs to maintain good relations and be internally embedded in a network of researchers to encourage them to share their IP and participate in the UITT process.

H2. Internal embeddedness is positively related to TTO performance.

\subsection{Marketing capabilities}

The marketing capabilities of the TTO are defined as the extent to which a TTO is able to perform marketing tasks related to technology transfer. These tasks may involve organizing partnering events, creating a user-friendly online knowledge map of the patents and exploitable technologies available within the university, etc. 
The university's exploitable technologies are mostly the result of basic research, which are not primarily motivated by industrial purposes but rather scientific curiosity (Perkmann et al., 2013). The emerging results often halt within the framework of the research group due to academics' lack of commercial motivations and competencies (Bercovitz and Feldman, 2006); thus, university TTOs usually do not even know about marketable technologies. TTOs are charged with the responsibilities to act as a business intermediary between academics and external stakeholders by taking an initiating role. The commercialization of technologies often requires special marketing qualifications and skills, which researchers do not always possess, while stakeholders claim they have shortcomings (Swamidass and Vulasa, 2009). Thus, the more a TTO is equipped with marketing capabilities, the more likely the TTO will achieve high performance.

H3. Marketing capabilities are positively related to TTO performance.

\subsection{Patent portfolio management}

Strict patent portfolio management by the TTO is defined as its preference for keeping only those technologies within the portfolio that have significant business potential. TTOs that follow strict patent portfolio management discard those technologies from the portfolio that do not generate significant interest from the industry within a considerable amount of time and keep only those technologies that have significant business potential.

Traditionally, the main task of TTOs has been to ensure the patent protection of IP produced at universities, which results in licensing. The university patenting protocol is typically different from the industrial protocol, as a large number of basic research results are produced at universities day by day, but only a fraction is eventually patented; moreover, a significant proportion stops at the level of the research group or departments and remains unknown to the TTO (Bercovitz and Feldman, 2006).

The central element of the university technology transfer process is materialized knowledge in the form of a patent (Reeves, 2006). However, a patent should not be considered an end product; therefore, mere patent accumulation is not an efficient strategy (Sorensen and Chambers, 2008). Only a small percentage of university IP is eventually patented. The attitude of the TTO toward patents and the stricter and more commercialization-oriented management of the patent portfolio can influence stakeholders' opinions about the TTO. Strict portfolio management means that the TTO only includes IP in the patent portfolio that potentially generates a benefit to business. By doing so, instead of general patent accumulation, the TTO strictly filters and eliminates items of lower market potential. We assume that stricter patent portfolio management has a positive effect on opinions about TTOs since it shows an effort to be effective, which in turn enhances positive perceptions.

H4. Strict patent portfolio management is positively related to TTO performance.

\subsection{Contingent role of region of operation}

In 1980, in the United States, the Bayh-Dole Act created legal and institutional frameworks for effective technology transfer activities at universities. As a result, these institutions established a presence in the market as knowledge exploiters. This legislation passed IP rights from the federal government to the universities. This gave them the opportunity to profit from on-campus research and turns the results into innovative and practical goods. In Europe and Japan, this process took place years later. For example, in Germany, inspired by the Bayh-Dole Act, the Bundesministerium für Bildung Forschung (BMBF) (Federal Ministry for Science and Education) became active only in 2002, more than 20 years after Bayh-Dole was implemented in the United States (Grimm and Jaenicke, 2012). Similarly, in Japan, the Japanese government introduced the industry-university collaborations policy in 
the late 1990s through the Technology Licensing Office Act in 1998 and the Japanese BayhDole Act in 1999, almost 20 years after the US Bayh-Dole Act was introduced in 1980 (Ito et al., 2016).

In Japan, prior to the launch of the 1998 Law to Promote Transfer of University Technologies, strong barriers existed between academia and industry for several reasons, including the legal restrictions placed on university researchers from seeking consultations outside academia, financially benefitting from entrepreneurial activity and using research and development funds to cover salaries and stipends (Etzkowitz et al., 2008). The change in legislation aimed to encourage entrepreneurial attitudes in university researchers in Japan. For example, the law legalized the compensated consulting of researchers and the holding of management positions in private companies (Etzkowitz et al., 2008).

The European and Japanese approaches have led to similar results in terms of increasing the number of patent applications (Takahashi and Carraz, 2011), while universities have entered the business market as active actors in technology transfer. TTOs and technology license offices (TLOs) have been established within universities (or outside but closely related to them) in these economies. The task of these units has been to facilitate the legal protection and commercialization of IP (Jensen and Thursby, 2001; Pawlowski et al., 2000). Table 3 summarizes the key differences of TTOs in Europe and Japan.

Among the investigated independent variables that affect TTO performance, we focus on the differential effects of patent portfolio management in Europe and Japan; this is one factor that is, to a great extent, driven by legal environments that may differ in various countries.

As Table 3 shows, in Japan, patenting rates are higher compared with the United States, while industry funding is more common in the United States. Ito et al. (2016) also confirm that rates of university patents in Japan are particularly high compared with the United Kingdom: "However, Japanese universities currently possess, arguably, too many patents and receive relatively low income from patents, resulting in significant pressure on their budgets." Patent portfolio management is less strict in Japan, as the number of patents held by university TTOs exceeds the Western average (Ito et al., 2016; Walsh and Huang, 2014). Based on this, we can assume that strict patent portfolio management is a weaker expectation among stakeholders in Japan, and that it will thus have a weaker effect on opinions regarding the performance of TTOs.

H5. In the case of Japanese TTOs, strict patent portfolio management will have a weaker effect on TTO performance than in the case of European TTOs.

\section{Methods}

\subsection{Research context and data collection}

The data for this study were collected through a survey that was sent to TTOs operating in European and Japanese higher educational institutions. We chose the European TTOs as the context for our investigation, because while European TTOs show diversity in terms national specificities, yet they are homogenous in the sense of being less professional compared to their US counterparts resulting into fewer patents (Gerbin and Drnovsek, 2016; Bacchiocchi and Montobbio, 2009). The Japanese TTOs has a number of characteristics that make them unique compared to their European and US counterparts, including that Japanese TTOs have been set up late compared to their American and European counterparts; yet, the patenting rate is high compared to other countries, including the United States, while the higher education system is rather centralized (Etzkowitz et al., 2008; Ito et al., 2016). These unique features make Japan a prime context for studying the region and country-specific characteristics.
University technology transfer offices 


\section{IJPPM}

\begin{tabular}{rr}
\hline Europe & Japan \\
\hline
\end{tabular}

TTO settings and the influence of the state

TTO patenting practices and revenues

(1) Overall increase in university patenting and magnitude is inferior relative to the United States (Bacchiocchi and Montobbio, 2009)

(2) Strong national specificities in different countries (Bacchiocchi and Montobbio, 2009)

(3) European revenue from academicindustry knowledge transfer is highly concentrated, with the top $10 \%$ of universities accounting for almost $90 \%$ of all revenue (Gerbin and Drnovsek, 2016)

(4) Compared to the United States, European management of knowledge and IP is less professional and results into fewer patents (Gerbin and Drnovsek, 2016)

\section{Researchers' positions and attitudes}

Table 3.

Selected empirical studies on key differences of TTOs between Europe and Japan
(1) Centralized higher education (HE) system (Etzkowitz et al., 2008)

(2) Significant government HE influence (Etzkowitz et al., 2008)

(3) Government-imposed restrictions over interactions between universities and industry (Etzkowitz et al., 2008)

(4) Most TTOs affiliated with national universities are independent for profit corporations (to be able to hire competent staff at competitive salaries, which would not have been allowed if they had been university offices) (Etzkowitz et al., 2008)

(5) Managers are less close to researchers and managers of their universities (Etzkowitz et al., 2008)

(1) Income relies largely on income from patent licensing, compared to the United Kingdom, where income includes sale of shares in spin-off companies and Intellectual Property (IP) income includes nonsoftware licensing, software licensing, and others (Ito et al., 2016)

(2) Universities possess too many patents and receive relatively low income from patents, resulting in significant pressure on their budgets (Ito et al., 2016)

(3) Patenting rates are higher compared to the United States (Walsh and Huang, 2014)

(4) Patents are less directly linked to commercial activity compared to the United States (Walsh and Huang, 2014)

(1) Lifetime employment in academia with seniority-based wages and retirement benefits (Etzkowitz et al., 2008)

(2) Since early 2000, university researchers can hold outside management positions, receive sponsored research from companies and hold stock or have an advisory or management position (Etzkowitz et al., 2008)

As a research frame, we used the Association of European Science and Technology Transfer Professionals for the European TTO sample that counts over 800 members (https://attp.info/ learn-about-attp/) and the TTOs of the 86 National Universities of Japan; convenience sampling technique was used in case of both the European and the Japanese TTOs. The 
questionnaire was sent in an online form in English for the European sample, whereas the Japanese questionnaire was first translated into Japanese, back-translated for correction, translated back into Japanese again and then finally proofread by a native speaker. During the research, no ethical issues have been raised, as the response to the questionnaire was voluntary, based on the respondent's consent. We have treated the responses anonymously and used it for scientific purposes only in an aggregated manner.

The data gathering is not the result of experiments with participants or animals. The data collection resulted in 187 completed questionnaires.

The sample characteristics are presented in Table 4.

The respondents have an average of 13 years of relevant work experience, so they presumably have proper insight into the operation of TTOs. In the course of collecting the data, we analyzed the sampling error resulting from nonresponse with a statistical method. Based on Armstrong and Overton's (1977) methodology, we compared the values of key variables found in our model in the quickly and slowly responding sub-samples, but we did not find significant differences. Analysis of variance did not indicate significant differences between the means of the key constructs between early and late respondents (Armstrong and Overton, 1977). Therefore, we concluded that nonresponse errors would not cause a systematic error in the sample, so we pooled data for subsequent analyses.

\subsection{Measures}

To enhance metrics reliability, the questionnaire was tested in a two-stage process. First, two academics evaluated the questionnaire. One of them, a former TTO director with notable experience in technology transfer, evaluated the statements according to their fit with TTO processes and proposed additional statements if he deemed it necessary. The other academic, one with several decades of experience in academic research, performed a semantic review of the questionnaire. Second, two TTO directors and two researchers tested the questionnaire. We asked them to mark all statements that they found confusing, incoherent or difficult to respond to. They were asked to briefly describe their problems with each item. We used fivepoint Likert-type scales to measure the concepts in our model. Each construct (TTO performance, social embeddedness, internal embeddedness, marketing capabilities and patent portfolio management) was measured with multi-item scales and consisted of at least three items (Table A1).

\subsection{Measurement instrument validation}

The validity and properties of the multi-item scales were assessed through confirmatory factor analysis (CFA) using IBM SPSS and AMOS softwares for the five constructs of performance, patenting, embeddedness, marketing and public value. The CFA results indicate a good fit (main fit indices: $\chi^{2} / \mathrm{df}=1.89, p<0.01, \mathrm{CFI}=0.92$, IFI $=0.92$, TLI $=0.90$ and RMSEA $=0.07$ ) based on the accepted cut-off values (Byrne, 2010). Factor loadings are statistically significant for each construction, the values of which exceed the threshold value

\begin{tabular}{lcccrr}
\hline & & \multicolumn{2}{c}{ Respondent position } \\
Region/country & TTO head & TTO employee & Scholar/researcher & Missing & Sum \\
\hline Europe $^{\text {a }}$ & 34 & 38 & 11 & 0 & 83 \\
Japan & 11 & 32 & 36 & 25 & 104 \\
Sum & 45 & 70 & 47 & 25 & 187
\end{tabular}

Note(s): ainvestigated countries are: Austria, Belgium, Croatia, Czech Republic, Denmark, Finland, Germany, Hungary, Ireland, Italy, the Netherlands, Norway, Poland, Portugal, Slovenia, Spain, Switzerland and United Kingdom
University technology transfer offices

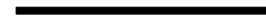




\section{IJPPM}

Table 5.

Validity and reliability of measurement scales of 0.6 (Anderson and Gerbing, 1988). The indices measuring the validity of all constructions in the model (composite reliability and Cronbach's alpha) exceed the threshold value of 0.7 . The average variance extracted (AVE) values surpass the threshold value of 0.5 in each case (Bagozzi and Yi, 1988). The outcomes from these tests support the convergent validity of the constructs used. Furthermore, the square of the intercorrelation between two constructs is less than the AVE estimates of the two constructs for all pairs of constructs, thus providing support for discriminant validity (Fornell and Larker, 1981). Table 5 presents the descriptive statistics for the model's key constructs.

\section{Analyses and results}

We tested our model using structural equation modeling (SEM) using AMOS 23.0 software. The fit indices show good values $\chi^{2}(93)=176.6, \chi^{2} / \mathrm{df}=1.899, p<0.001$; RMSEA $=0.071$; $\mathrm{SRMR}=0.072 ; \mathrm{NNFI}=0.904$ and $\mathrm{CFI}=0.926)$. We summarized the results of the model testing in Table 6.

Our results supported the first hypothesis $(b=0.199$ and $p<0.05)$ that social embeddedness has a positive effect on the assessment of TTO performance; hence, social embeddedness enables TTO members the sharing of knowledge within a larger network. These findings are in line with the current understanding of knowledge dynamics that highly hinges on the integration of diverse information from the network of sources (Marques, 2019). Our results support the second hypothesis $(b=0.29$ and $p<0.01)$. Internal embeddedness plays an important role in human resource productivity, such as reducing turnover intentions (Coetzer et al., 2019). Our study shows that the internal embeddedness of TTOs positively influences TTO performance. These results are in accordance with the prior literature and may be explained by the underlying mechanisms of embedded TTO members being more legitimate in the eyes of researchers, which in turn improves performance outcomes (O'Kane et al., 2015). The third hypothesis that marketing capabilities have a positive effect on

\begin{tabular}{lcccccccccr}
\hline Variable & Mean & Std. dev. & CR & CA & AVE & SUC & MAR & SE & PAT & IE \\
\hline PRF & 2.42 & 0.94 & 0.81 & 0.80 & 0.60 & 0.77 & & & & \\
MAR & 2.90 & 0.95 & 0.81 & 0.79 & 0.53 & 0.29 & 0.73 & & & \\
SE & 3.06 & 0.71 & 0.77 & 0.76 & 0.54 & 0.38 & 0.22 & 0.74 & & \\
PAT (po) & 3.05 & 1.01 & 0.78 & 0.76 & 0.55 & -0.01 & 0.07 & 0.07 & 0.74 & \\
IE & 2.67 & 1.07 & 0.78 & 0.77 & 0.55 & 0.27 & 0.03 & 0.25 & 0.12 & 0.74
\end{tabular}

Note(s): PRF: TTO performance; MAR: marketing capabilities; SE: social embeddedness; PAT: strictness of TTO patent portfolio management; IE: internal embeddedness; CR: composite reliability; CA: Cronbach's alpha and AVE: average variance extracted. The square root of AVE is shown on the diagonal
Table 6.

Parameter estimation (standardized structural coefficient) and variance explained $\left(R^{2}\right)$

\begin{tabular}{lcc}
\hline & $\begin{array}{c}\text { Standardized structural } \\
\text { coefficient }\end{array}$ & $\begin{array}{c}\text { Variance explained } \\
\left(R^{2}\right)\end{array}$ \\
\hline H1: Social embeddedness $\rightarrow$ TTO performance & $0.199^{* *}$ \\
H2: Internal embeddedness $\rightarrow$ TTO performance & $0.290^{* *}$ & \\
H3: Marketing capabilities $\rightarrow$ TTO performance & $0.228^{* *}$ & 0.23 \\
H4: Patent portfolio management $\rightarrow$ TTO & $-0.078 \mathrm{~ns}$ & \\
performance & & \\
TTO performance & & \\
Note(s): ${ }^{*} p<0.05 ;{ }^{* * *} p<0.01 . \mathrm{ns}=$ not significant & &
\end{tabular}


TTO performance is also supported by the data $(b=0.22$ and $p<0.01)$. Although it has received less attention in the context of UITT, and TTOs specifically, marketing capabilities' impact on firm performance was found to be positive in various industries and studies (Kamboj and Rahman, 2015; Jaisinghani et al., 2019). The positive result may be explained by scientists' basic research outcomes - often being motivated by pure scientific curiosity combined with TTOs' capabilities to effectively market research outcomes and improve TTO performance (Perkmann et al., 2013; Swamidass and Vulasa, 2009). The empirical results do not support the fourth hypothesis $(b=-0.07$ and n.s.) that strict patent portfolio management has a positive effect on TTO performance. Contrary to the preliminary hypotheses, our results tend to confirm that a strong focus on patent portfolio management may even reduce TTO efficiency, as suggested by studies proposing a more holistic approach to examining the performance of TTOs (Molas-Gallart and Castro-Martínez, 2007; Secundo et al., 2016).

The fifth hypothesis states that strict patent portfolio management has a weaker effect on opinions regarding the performance of TTOs among Japanese TTOs than among European TTOs. To reveal whether geographical origins (Japan or Europe) have a moderating effect on the relationship between patent portfolio management and the assessment of TTOs, we carried out a multi-group moderation test. We examined through critical ratios (z-scores) whether strict patent portfolio management determines the performance of TTOs to significantly different extents in the case of Japanese and European TTOs (Byrne, 2010).

The results presented in Table 7 show that strict patent portfolio management has a significant negative effect $(b=-0.302$ and $p<0.05)$ on TTO performance in Europe but has no significant effect on Japan ( $b=0.055$, ns), and that the difference between the two groups is significant $(\phi<0.10)$. According to Hypothesis 5, strict TTO patent portfolio management in Japan has a weaker effect on opinions regarding TTO performance than it does in Europe. Our results do not confirm this hypothesis; thus, H5 is rejected.

\section{Conclusions and contributions}

\subsection{Response to research questions and synthesis of findings}

The primary goal of this study is to enrich the technology transfer literature by suggesting an intangible, perception-based operationalization of TTO performance by capturing relevant but yet not investigated factors that influence performance and by highlighting the importance of region-specific differences. More specifically, we aim to answer the following research questions: (1) what factors influence intangible, perception-based TTO performance, and (2) does the role of patent portfolio management contribute to TTO performance differently in Europe than in Japan?

The conceptual starting point of our study is that in addition to traditional first and second missions of teaching and academic research, universities increasingly need to take part in the

\begin{tabular}{lccccc}
\hline & \multicolumn{4}{c}{} & \multicolumn{2}{c}{$\begin{array}{c}\text { Significance level of the } \\
\text { European TTOs } \\
(n=77)\end{array}$} & \multicolumn{2}{c}{$\begin{array}{c}\text { Japanese TTOs } \\
(n=104)\end{array}$} & $\begin{array}{c}\text { difference between European and } \\
\text { Japanese TTOs }\end{array}$ \\
$\begin{array}{c}\text { Std. } \\
\text { beta }\end{array}$ & $\begin{array}{c}\text { Sig. } \\
\text { level }\end{array}$ & $\begin{array}{c}\text { Std. } \\
\text { beta }\end{array}$ & $\begin{array}{c}\text { Sig. } \\
\text { level }\end{array}$ & $z$-score \\
\hline $\begin{array}{l}\text { H5: Patent portfolio } \\
\text { management } \rightarrow \text { TTO } \\
\text { performance }\end{array}$ & -0.302 & 0.012 & 0.055 & 0.705 & $1.894^{*}$
\end{tabular}

Note(s): $z$-score significance: 0.01 level if it is greater than 2.58, 0.05 level if greater than 1.96 and 0.10 level if greater than 1.65 (Byrne, 2010). ${ }^{*} p<0.05$
University technology transfer offices

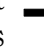


generation, use, application and exploitation of knowledge outside academic environments as catalysts of societal and economic innovation (Molas-Gallart and Castro-Martínez, 2007). This new task, often labeled as the third mission, puts universities in an original position, and many of them have set up TTOs to facilitate technology transfer. TTO performance is often evaluated by output-oriented tangible metrics; however, as recent research points out, the legitimacy of intangible metrics is unquestionable, as these metrics provide a more nuanced picture of TTO efficiency (De Beer et al., 2017; Secundo et al., 2016).

Our study proposes a new perception-based scale for capturing intangible TTO performance and empirically validates this scale on a sample of various TTO stakeholders, such as TTO heads, TTO employees and university researchers. Our findings suggest that four factors - social embeddedness, internal embeddedness, marketing capabilities and patent portfolio management - all of which are related to the knowledge-based view explain $23 \%$ of the variance in TTO performance. The most important variable is the internal embeddedness of the TTO (i.e. the TTO is in possession of accurate information on innovations available within the university, there are scientific products and services that can be sold to industrial partners and the TTO is generally accepted as the exploiter of university inventions within the university). Our results indicate that the effect of patenting practices (e.g. only technologies with high business potential are worth patenting) on TTO performance is contingent on the region in which the TTO operates. In Europe, strict patenting practices have a significant negative effect on TTO performance. However, in Japan, where universities were prohibited from commercializing IP until 1998 and where TTOs have only played a role in technology transfer since 2004, strict patenting has no significant effect on TTO performance.

\subsection{Theoretical contributions}

This research enhances our understanding of how the environment/region of operation moderates the factors that affect TTO performance. More specifically, our empirical study of 18 countries in Europe and Japan provides robust evidence on the differential effect of patent portfolio management on TTO performance. Our findings in the European sub-sample, which suggest that strict patent portfolio management has a negative effect on TTO performance, provide an important contribution to the UITT literature. Former studies did not specifically look at the direct link between TTO performance and patenting practices; however, Siegel et al. (2003) point out that $80 \%$ of their respondents expressed dissatisfaction with TTOs exercising their IP rights too aggressively and being too concerned with a very narrow focus on the legal aspects of licensing. In Japan, however, where - compared with international standards - TTO income is largely derived from patent licensing (Ito et al., 2016), and patenting rates are higher (Walsh and Huang, 2014), TTO stakeholders seem to be neutral toward the strictness of TTO patent portfolio management when evaluating its performance.

In contrast to prior research, which has typically associated sales or profitability (market impact), or the number of the university's patent applications (Clarysse et al., 2011; Zaichenko, 2018; Sellenthin, 2009) with TTO performance primarily, we find that perception-based intangible metrics of TTO performance can be used and validated in a multi-country, multistakeholder context. This is an important finding for the UITT literature and supports recent new avenues for other capability-based intangible TTO performance metrics (e.g. Muscio, 2010; De Beer et al., 2017; Secundo et al., 2016).

Extant studies of performance metrics in the context of universities highlight the importance of management and strategy, such as transparency, description of objectives, quality of plans, etc. (Angiola et al., 2018). Studies on TTO performance, however, place more emphasis on understanding the roles of individuals in this process by uncovering the 
confidence of academics in TTOs, the TTO managers' industry background (Muscio, 2010) or the experience with the patenting system (Sellenthin, 2009), while factors related to the organization and the relationship between the university and other actors remain unexplored. As a theoretical contribution, by applying the knowledge-based view as a conceptual lens, this study highlights the roles of marketing capabilities, patent portfolio management and internal embeddedness as organizational factors and social embeddedness as an interorganizational factor in enhancing TTO performance.

\subsection{Managerial contributions}

This study might be of interest to both university management and TTO members. The former is interested in finding ways to foster the technology transfer process and raise its effectiveness, while the latter group seeks the means to improve the performance and legitimacy of the TTO.

We found that the internal embeddedness of the TTO and thereby its direct relationship with researchers as well as its possession of adequate information on university technologies are all important for stakeholder expectations. They underlie the significance of the scientific identity of the TTO. This means that it is not sufficient to merely fulfill industrial criteria; legitimacy in the eyes of the researchers is also essential for performance; thus, establishing personal contacts is crucial. Therefore, our first recommendation for university management is to support events that facilitate personal interactions between TTO staff and university researchers. Such events may include innovation days and innovation clubs. The former represents more formal ways for UITT managers and researchers to establish contact, while the latter represents more informal ones.

Our second managerial implication is based on the result that a business identity also proves to be important in terms of the performance of a TTO, which necessitates appropriate marketing activities. These are particularly expensive activities - especially regular visits to international partnering events - but we would like to draw university decision-makers' attention to the fact that this is still essential for effective TTO activity. Stakeholders rightly expect that one of the most market-oriented organizational units at the university builds an actual business-like image and engages in substantive marketing activities.

Our third recommendation is addressed to TTO managers and directors. The most insightful result of our research is the negative (or neutral in the case of Japan) assessment regarding strict patent portfolio management, traditionally viewed as a core activity of TTOs. On the one hand, we found that strict TTO patent portfolio management has no significant effect on stakeholders' opinions in the total sample. On the other hand, the European subsample showed that strict patent portfolio management has a negative effect on the assessment of TTO performance. It seems that stakeholders expect more than simple patent administration. Strict patent regulation can easily lead to restricting the TTO in its scope of action in terms of both portfolio and available resources. As far as this is concerned, we advise TTO managers to focus more on an effective application of marketing tools besides, or even instead of, portfolio revision and screening. This approach involves a more efficient exploration of new research results and an easy-to-access on/offline presentation of portfolios.

Another important finding is that, in addition to business aspects, the relevance of social aspects is also noted, as social embeddedness proved to be a criterion for high-performance university technology transfer. Our fourth recommendation is for university managers to maintain a closer relationship with the local community and to consider social aspects, though this often contradicts the exclusivity granted by a patent. Maintaining social ties also represents a change in approach since it requires decision-makers to engage in more holistic thinking that covers several stakeholders instead of mere business partners, which is also closely linked to the fulfillment of universities' third mission. 


\section{Limitations and future research directions}

As with any research, this study has several limitations that offer potential avenues for further research. Our study offers a multi-continent perspective and, on a more general level, highlights the importance of moderators in modeling the factors that affect the process of UITT. Further research may warrant examining the difference in perceptions among various technology transfer stakeholders. For example, the factors that affect TTO performance may be different from the perspective of a researcher than that of a TTO manager or employee.

Although empirical evidence of this study suggests that the contextual setting of the UITT moderates the role of important factors, some countries and regions that can provide contexts for studying UITT are as of yet missing from the literature. For example, the process of UITT is well studied in Europe, but even on this continent, we can find regions that are terra incognita. While countries of "old" Europe, such as the United Kingdom, Spain, France and Italy, are the focus of researchers (Tartari and Salter, 2015; Marzocchi et al., 2017; Clarysse et al., 2011; Tartari et al., 2014; Forti et al., 2013; Olaya Escobar et al., 2017), we have very limited knowledge of the UITT in regions of "new" Europe, such as the countries of Central and Eastern Europe and the former Soviet Union. We hope that researchers will increasingly find opportunities to collect data from these regions, especially because academic-industry knowledge transfer is highly concentrated in Europe, with the top 10\% of universities (mainly from "old” Europe) accounting for almost $90 \%$ of all revenue (Gerbin and Drnovsek, 2016). Hence, our extant knowledge on UITT in Europe is derived from studies on more industrialized regions, while less is known about the specific features of UITT in lower industrial output regions.

\section{References}

Aldridge, T.T. and Audretsch, D. (2011), "The Bayh-Dole act and scientist entrepreneurship”, Research Policy, Vol. 40 No. 8, pp. 1058-1067.

Anderson, J.C. and Gerbing, D.W. (1988), "Structural equation modeling in practice: a review and recommended two-step approach", Psychological Bulletin, Vol. 103 No. 3, pp. 411-423.

Angiola, N., Bianchi, P. and Damato, L. (2018), "Performance management in public universities: overcoming bureaucracy", International Journal of Productivity and Performance Management, Vol. 67 No. 4, pp. 736-753.

Armstrong, J.S. and Overton, T.S. (1977), "Estimating nonresponse bias in mail surveys", Journal of Marketing Research, Vol. 14 No. 3, pp. 396-402.

Bacchiocchi, E. and Montobbio, F. (2009), "Knowledge diffusion from university and public research. A comparison between US, Japan and Europe using patent citations", The Journal of Technology Transfer, Vol. 34 No. 2, pp. 169-181.

Bagozzi, R.P. and Yi, Y. (1988), "On the evaluation of structural equation models", Journal of the Academy of Marketing Science, Vol. 16 No. 1, pp. 74-94.

Bercovitz, J. and Feldman, M. (2006), "Entprepreneurial universities and technology transfer: a conceptual framework for understanding knowledge-based economic development", The Journal of Technology Transfer, Vol. 31 No. 1, pp. 175-188.

Bozeman, B. (2000), "Technology transfer and public policy: a review of research and theory", Research Policy, Vol. 29 No. 4, pp. 627-655.

Bozeman, B., Rimes, H. and Youtie, J. (2015), "The evolving state-of-the-art in technology transfer research: revisiting the contingent effectiveness model”, Research Policy, Vol. 44 No. 1, pp. 34-49.

Byrne, B.M. (2010), Structural Equation Modeling with AMOS: Basic Concepts, Applications and Programming, Routledge, Taylor \& Francis Group, New York, NY. 
Carayannis, E.G. and Campbell, D.F. (2009), “'Mode 3' and 'Quadruple Helix': toward a 21st century fractal innovation ecosystem", International Journal of Technology Management, Vol. 46 Nos 3-4, pp. 201-234.

Chen, H.L., Ho, M.H.C. and Hsu, W.T. (2013), "Does board social capital influence chief executive officers' investment decisions in research and development?", R\&D Management, Vol. 43 No. 4, pp. 381-393.

Clarysse, B., Tartari, V. and Salter, A. (2011), "The impact of entrepreneurial capacity, experience and organizational support on academic entrepreneurship", Research Policy, Vol. 40 No. 8, pp. 1084-1093.

Coetzer, A., Inma, C., Poisat, P., Redmond, J. and Standing, C. (2019), "Does job embeddedness predict turnover intentions in SMEs?", International Journal of Productivity and Performance Management, Vol. 68 No. 2, pp. 340-361.

Comacchio, A., Bonesso, S. and Pizzi, C. (2012), "Boundary spanning between industry and university: the role of technology transfer centres", The Journal of Technology Transfer, Vol. 37 No. 6, pp. 943-966.

Conti, A. and Liu, C.C. (2015), "Bringing the lab back in: personnel composition and scientific output at the MIT department of biology", Research Policy, Vol. 44 No. 9, pp. 1633-1644.

Criaco, G., Minola, T., Migliorini, P. and Serarols-Tarrés, C. (2014), "'To have and have not': founders' human capital and university start-up survival", The Journal of Technology Transfer, Vol. 39 No. 4, pp. 567-593.

Croce, A., Grilli, L. and Murtinu, S. (2014), "Venture capital enters academia: an analysis of universitymanaged funds", The Journal of Technology Transfer, Vol. 39 No. 5, pp. 688-715.

de Wit-de Vries, E., Dolfsma, W.A., van der Windt, H.J. and Gerkema, M. (2018), "Knowledge transfer in university-industry research partnerships: a review", The Journal of Technology Transfer, Vol. 44 No. 4, pp. 1236-1255.

De Beer, C., Secundo, G., Passiante, G. and Schutte, C.S. (2017), "A mechanism for sharing best practices between university technology transfer offices", Knowledge Management Research and Practice, Vol. 15 No. 4, pp. 523-532.

Estrada, I., Faems, D., Cruz, N.M. and Santana, P.P. (2016), "The role of interpartner dissimilarities in industry-university alliances: insights from a comparative case study", Research Policy, Vol. 45 No. 10, pp. 2008-2022.

Etzkowitz, H., Ranga, M., Benner, M., Guaranys, L., Maculan, A.M. and Kneller, R. (2008), "Pathways to the entrepreneurial university: towards a global convergence", Science and Public Policy, Vol. 35 No. 9, pp. 681-695.

Fornell, C. and Larker, D.F. (1981), "Evaluating structural equation models with unobservable variables and measurement errors", Journal of Marketing Research, Vol. 18 No. 1, pp. 39-50.

Forti, E., Franzoni, C. and Sobrero, M. (2013), "Bridges or isolates? Investigating the social networks of academic inventors", Research Policy, Vol. 42 No. 8, pp. 1378-1388.

Freitas, I.M.B., Marques, R.A. and e Silva, E.M.D.P. (2013), "University-industry collaboration and innovation in emergent and mature industries in new industrialized countries", Research Policy, Vol. 42 No. 2, pp. 443-453.

Galán-Muros, V. and Plewa, C. (2016), "What drives and inhibits university-business cooperation in Europe? A comprehensive assessment”, R\&D Management, Vol. 46 No. 2, pp. 369-382.

Galán-Muros, V. and Davey, T. (2017), "The UBC ecosystem: putting together a comprehensive framework for university-business cooperation”, The Journal of Technology Transfer, Vol. 44 No. 4, pp. 1311-1346.

Gerbin, A. and Drnovsek, M. (2016), "Determinants and public policy implications of academicindustry knowledge transfer in life sciences: a review and a conceptual framework", The Journal of Technology Transfer, Vol. 41 No. 5, pp. 979-1076.
University technology transfer offices 
Grant, R.M. (1996), "Toward a knowledge-based theory of the firm”, Strategic Management Journal, Vol. 17 No. S2, pp. 109-122.

Grimm, H.M. and Jaenicke, J. (2012), "What drives patenting and commerzialisation activity at East German universities? The role of new public policy, institutional environment and individual prior knowledge", The Journal of Technology Transfer, Vol. 37 No. 4, pp. 454-477.

Guerzoni, M., Aldridge, T.T., Audretsch, D.B. and Desai, S. (2014), "A new industry creation and originality: insight from the funding sources of university patents", Research Policy, Vol. 43 No. 10, pp. 1697-1706.

Haeussler, C. and Colyvas, J.A. (2011), "Breaking the ivory tower: academic entrepreneurship in the life sciences in UK and Germany", Research Policy, Vol. 40 No. 1, pp. 41-54.

Hayter, C.S. (2016), "Constraining entrepreneurial development: a knowledge-based view of social networks among academic entrepreneurs", Research Policy, Vol. 45 No. 2, pp. 475-490.

Ito, T., Kaneta, T. and Sundstrom, S. (2016), "Does university entrepreneurship work in Japan?: a comparison of industry-university research funding and technology transfer activities between the UK and Japan", Journal of Innovation and Entrepreneurship, Vol. 5 No. 1, pp. 8-29.

Jaisinghani, D., Kaur, H., Goyal, J. and Joshi, M. (2019), "Marketing intensity and persistence of firm performance: empirical evidence from Indonesia", International Journal of Productivity and Performance Management, Vol. 69 No. 6, pp. 1109-1127.

Jensen, R. and Thursby, M. (2001), "Proofs and prototypes for sale: the tale of university licensing", American Economic Review, Vol. 91 No. 1, pp. 240-259.

Jha, Y. and Welch, E.W. (2010), "Relational mechanisms governing multifaceted collaborative behavior of academic scientists in six fields of science and engineering", Research Policy, Vol. 39 No. 9, pp. 1174-1184.

Johnson, W.H. (2011), "Managing university technology development using organizational control theory”, Research Policy, Vol. 40 No. 6, pp. 842-852.

Kamboj, S. and Rahman, Z. (2015), "Marketing capabilities and firm performance: literature review and future research agenda", International Journal of Productivity and Performance Management, Vol. 64 No. 8, pp. 1041-1067.

Kodama, T. (2008), "The role of intermediation and absorptive capacity in facilitating universityindustry linkages - an empirical study of TAMA in Japan”, Research Policy, Vol. 37 No. 8, pp. 1224-1240.

Laredo, P. (2007), "Revisiting the third mission of universities: toward a renewed categorization of university activities?”, Higher Education Policy, Vol. 20 No. 4, pp. 441-456.

Levy, R., Roux, P. and Wolff, S. (2009), "An analysis of science-industry collaborative patterns in a large European university”, The Journal of Technology Transfer, Vol. 34 No. 1, pp. 1-23.

Marion, T.J., Dunlap, D.R. and Friar, J.H. (2012), "The university entrepreneur: a census and survey of attributes and outcomes", R\&D Management, Vol. 42 No. 5, pp. 401-419.

Marques, L. (2019), "Sustainable supply network management: a systematic literature review from a knowledge perspective", International Journal of Productivity and Performance Management, Vol. 68 No. 6, pp. 1164-1190.

Marzocchi, C., Kitagawa, F. and Sánchez-Barrioluengo, M. (2017), "Evolving missions and university entrepreneurship: academic spin-offs and graduate start-ups in the entrepreneurial society", The Journal of Technology Transfer, Vol. 44 No. 1, pp. 167-188.

Miranda, F.J., Chamorro, A. and Rubio, S. (2017), "Re-thinking university spin-off: a critical literature review and a research agenda”, The Journal of Technology Transfer, Vol. 43 No. 4, pp. 1007-1038.

Molas-Gallart, J. and Castro-Martínez, E. (2007), "Ambiguity and conflict in the development of "third mission” indicators”, Research Evaluation, Vol. 16 No. 4, pp. 321-330.

Mowery, D.C. and Ziedonis, A.A. (2015), "Markets versus spillovers in outflows of university research", Research Policy, Vol. 44 No. 1, pp. 50-66. 
Munshaw, S., Lee, S.-H., Phan, P.H. and Marr, K.A. (2018), "The influence of human capital and perceived university support on patent applications of biomedical investigators", The Journal of Technology Transfer, Vol. 44 No. 4, pp. 1216-1235.

Muscio, A. (2010), "What drives the university use of technology transfer offices? Evidence from Italy", The Journal of Technology Transfer, Vol. 35 No. 2, pp. 181-202.

M'Chirgui, Z., Lamine, W., Mian, S. and Fayolle, A. (2016), "University technology commercialization through new venture projects: an assessment of the French regional incubator program", The Journal of Technology Transfer, Vol. 43 No. 5, pp. 1142-1160.

Nelson, R.R. (2004), "The market economy, and the scientific commons", Research Policy, Vol. 33 No. 3, pp. $455-471$.

Nonaka, I. (1994), “A dynamic theory of organizational knowledge creation”, Organizational Science, Vol. 5 No. 2, pp. 14-37.

Olaya Escobar, E.S., Berbegal-Mirabent, J., Alegre, I. and Duarte Velasco, O.G. (2017), “Researchers' willingness to engage in knowledge and technology transfer activities: an exploration of the underlying motivations", R\&D Management, Vol. 47 No. 5, pp. 715-726.

O'Kane, C., Mangematin, V., Geoghegan, W. and Fitzgerald, C. (2015), "University technology transfer offices: the search for identity to build legitimacy", Research Policy, Vol. 44 No. 2, pp. 421-437.

Pakes, A. and Griliches, Z. (1980), "Patents and R\&D at the firm level: a first report", Economics Letters, Vol. 5 No. 4, pp. 377-381.

Park, H.W. and Leydesdorff, L. (2010), "Longitudinal trends in networks of university-industrygovernment relations in South Korea: the role of programmatic incentives", Research Policy, Vol. 39 No. 5, pp. 640-649.

Pawlowski, S.D., Robey, D. and Raven, A. (2000), "Supporting shared information systems: boundary objects, communities, and brokering", Proceedings of the 21th International Conference on Information Systems, pp. 329-338.

Perkmann, M., Tartari, V., McKelvey, M., Autio, E., Broström, A., D’Este, P., Fini, R., Geuna, A., Grimaldi, R. and Hughes, A. (2013), "Academic engagement and commercialisation: a review of the literature on university-industry relations", Research Policy, Vol. 42 No. 2, pp. 423-442.

Powers, J.B. (2003), "Commercializing academic research: resource effects on performance of university technology transfer", The Journal of Higher Education, Vol. 74 No. 1, pp. 26-50.

Rampersad, G.C. (2015), "Developing university-business cooperation through work-integrated learning", International Journal of Technology Management, Vol. 68 Nos 3-4, pp. 203-227.

Reeves, R. (2006), Commercial Management of University Research and Patents-Working Paper, University of Bologna.

Robin, S. and Schubert, T. (2013), "Cooperation with public research institutions and success in innovation: evidence from France and Germany”, Research Policy, Vol. 42 No. 1, pp. 149-166.

Sandström, C., Wennberg, K., Wallin, M.W. and Zherlygina, Y. (2016), "Public policy for academic entrepreneurship initiatives: a review and critical discussion", The Journal of Technology Transfer, Vol. 43 No. 5, pp. 1232-1256.

Schwartz, E.I. (2004), Juice: The Creative Fuel that Drives Today's World-Class Inventors, Harvard Business school Press, Cambridge, MA.

Secundo, G., De Beer, C. and Passiante, G. (2016), "Measuring university technology transfer efficiency: a maturity level approach", Measuring Business Excellence, Vol. 20 No. 3, pp. 42-54.

Sellenthin, M.O. (2009), "Technology transfer offices and university patenting in Sweden and Germany", The Journal of Technology Transfer, Vol. 34 No. 6, pp. 603-620.

Siegel, D.S., Waldman, D. and Link, A. (2003), "Assessing the impact of organizational practices on the relative productivity of university technology transfer offices: an exploratory study", Research Policy, Vol. 32 No. 1, pp. 27-48.
University technology transfer offices 
Sorensen, J.A.T. and Chambers, D.A. (2008), "Evaluating academic technology transfer performance by how well access to knowledge is facilitated-defining an access metric", The Journal of Technology Transfer, Vol. 33 No. 5, pp. 534-547.

Spender, J.C. (1996), "Making knowledge the basis of a dynamic theory of the firm", Strategic Management Journal, Vol. 17 No. S2, pp. 45-62.

Stilgoe, J., Owen, R. and Macnaghten, P. (2013), "Developing a framework for responsible innovation”, Research Policy, Vol. 42 No. 9, pp. 1568-1580.

Swamidass, P.M. and Vulasa, V. (2009), "Why university inventions rarely produce income? Bottlenecks in university technology transfer", The Journal of Technology Transfer, Vol. 34 No. 4, pp. 343-363.

Takahashi, M. and Carraz, R. (2011), "Academic patenting in Japan: illustration from a leading Japanese university", Academic entrepreneurship in Asia. Edward Elgar, pp. 86-107, Cheltenham.

Tartari, V. and Salter, A. (2015), "The engagement gap: exploring gender differences in universityindustry collaboration activities", Research Policy, Vol. 44 No. 6, pp. 1176-1191.

Tartari, V., Perkmann, M. and Salter, A. (2014), "In good company: the influence of peers on industry engagement by academic scientists”, Research Policy, Vol. 43 No. 7, pp. 1189-1203.

Walsh, J.P. and Huang, H. (2014), "Local context, academic entrepreneurship and open science: publication secrecy and commercial activity among Japanese and US scientists", Research Policy, Vol. 43 No. 2, pp. 245-260.

Zaichenko, S. (2018), "The human resource dimension of science-based technology transfer: lessons from Russian RTOs and innovative enterprises", The Journal of Technology Transfer, Vol. 43 No. 2, pp. 368-388. 
Appendix

\section{Construct and definition}

TTO performance: the degree to which TTOs is perceived as being able to effectively commercialize technologies

Social embeddedness: TTOs active collaboration in value creation with external stakeholders

Internal embeddedness: TTOs active collaboration in value creation with internal stakeholders, such as researchers

Marketing capabilities: the extent to which a TTO is able to perform marketing tasks related to technology transfer

Patent portfolio management: Strict patent portfolio management of the TTO is defined as the TTOs' preference for keeping only those technologies within the portfolio that has significant business potential
Items

\section{transfer offices}

( $1=$ fully disagree and $5=$ fully agree $)$

(1) TTOs are achieved high performance from a business point of view

(2) Majority of university patents are applied by the industry with the assistance of TTO

(3) Many intellectual properties are commercialized with the assistance of TTO

( 1 = fully disagree and $5=$ fully agree)

(1) The interests of the local communities are taken into account in the university technology transfer

(2) Universities take part in open innovation processes with the assistance of TTOs

(3) There is a society control over the university innovation process

( 1 = fully disagree and $5=$ fully agree)

(1) TTOs actively collaborate with researchers during technology transfer processes

(2) The TTO is aware of all the exploitable technologies at the university

(3) The TTO is aware of all the scientific services and devices that can be capitalized by industrial partners

$(1=$ fully disagree and $5=$ fully agree $)$

(1) TTOs frequently visit international partnering events

(2) The TTO has a user-friendly online knowledge map (or patent portfolio)

(3) The brochures of the TTO on the university are business conform

(4) The homepage of the TTO is business conform

$(1=$ fully disagree and $5=$ fully agree $)$

(1) TTOs cancel patents that do not generate any interest from the industry within 3-4 years

(2) TTOs patent only those technologies that have significant business potential

(3) TTOs patent only those technologies that generate financial income to the university
Measurement constructs
Table A1.

\begin{abstract}
About the authors
Szabolcs Pronay is an associate professor at the Faculty of Economics and Business Administration at the University of Szeged. He holds a $\mathrm{PhD}$ degree on the topic of brand symbolism and brand loyalty and habilitated on the topic of B2B and B2C consumption communities. Szabolcs Pronay is the lecturer of several BA and MA marketing courses (including Consumer behavior, Pricing and Branding). He teaches these courses both in Hungarian and English.

Tamara Keszey is an Associate Professor and Head of the Marketing Management Department at the Corvinus University of Budapest, Hungary. She holds a Ph.D. in management sciences from the Corvinus University of Budapest. Her teaching and research interests cover customer cocreation, innovation and consumer adoption of innovations. Prior to her academic career, she had been working as
\end{abstract}


a senior IT consultant at KPMG Hungary. Tamara Keszey is the corresponding author and can be contacted at: tamara.keszey@uni-corvinus.hu

Norbert Buzás is an Associate Professor and head of the Department of Health Economics at Faculty of Medicine, University of Szeged. He holds a Ph.D. in Chemistry, a Master in Physics, Environmental Management and Business Administration. He was the founding director of the Directorate of Innovation Management and Technology Transfer at the University of Szeged. Dr. Buzás' research interest covers responsible innovation, science-to-business marketing, cocreation and behavioral economics in healthcare. He has about 100 publications, including 20 books and book chapters.

Takayuki Sakai is a Professor in the Graduate School of Science, Technology and Innovation at Kobe University, Japan and an advisor to the Kobe city government venture support consortium. Priorly, he worked a Professor at Tokushima University, president of Techno Network Shikoku (SHIKOKU TLO), the technology transfer office of the Shikoku Region and director of the Kansai Technology Transfer Organization (Kansai TLO) of Kyoto University. He has also served as assistant director of the Enterprise and Commercialization Division of Ritsumeikan University. Dr. Sakai was a visiting scholar at Cornell University's Center for Technology Enterprise and Commercialization.

Dr Kensuke Inai is an Associate Professor and deputy general director of the Center for Research Administration \& Collaboration at the Tokushima University, Japan. He holds a Ph.D. in Engineering from the Tokushima University. His research interest covers technology transfer, industry-academiagovernment collaboration and academic entrepreneurship.

For instructions on how to order reprints of this article, please visit our website: 